\title{
KEPEMIMPINAN KYAI DALAM USAHA MENGEMBANGKAN PENDIDIKAN ISLAM DI TPQ AS-SHOLIHI
}

\begin{abstract}
Abd Qomar*
Abstract: Quran Education Park (TPQ) is a growing phenomenon in the world of social society, as a form of educational park for early childhood. The phenomenon emerged as an alternative solution to kyai leadership in $T P Q$ and as one important factor in achieving the goal to overcome the difficulties of children, especially in learning the Qur'an. This is very urgent because TPQ is an institution of Islamic Education which grows and is recognized by the community. Based on the above thoughts, the authors are interested to conduct research related to the leadership of kyai in an effort to develop Islamic education in $T P Q$ As-sholihi Pajarakan. This study discusses the leadership of kyai in an effort to develop Islamic education in TPQ As-sholihi Pajarakan with the formulation of the problem as follows: 1) How is the Kyai leadership type in TPQ As-sholihi Pajarakan? 2) What efforts did the kyai make in developing Islamic education in TPQ As-sholihi Pajarakan? The purpose of this research is 1) Describe the type of leadership of Kyai in TPQ As-sholihi Pajarakan. 2) Identify kyai's efforts in developing Islamic education in TPQ As-sholihi Pajarakan. From the results of this study shows that TPQ in carrying out its function as a supporting unit of education in the community and in realizing the vision, its mission using the type of leadership kharismatik (authority kyai), authoritarian (punishment on santri) and democratic (cooperation with program supporters), it was seen on existing programs in TPQ. Types of leadership are run because of limited human resources (HR), especially in terms of acceptance of new students and skills improvement. While kyai business in developing Islamic education in TPQ As-sholihi Pajarakan is to maximize the program of increasing the competence of santri as well as improving the quality and quantity of worship. Both programs are directly directed by the TPQ leader as the person in charge who is the interpreter of TPQ's vision and mission.
\end{abstract}

Keywords: kyai, leadership, Islamic education

\section{A. Pendahuluan}

Pendidikan sejati merupakan proses sosial yang bertujuan untuk mengembangkan potensi hidup manusia baik secara individual maupun secara

* Dosen Tetap Institut Ilmu Keislaman Zainul Hasan Genggong Kraksaan Probolionggo 
sosial. Sebab dengan pendidikan, manusia dapat memerankan hidupnya sebagai makhluk yang paling mulia di dunia ini.

Selain itu pendidikan juga merupakan kebutuhan pokok dalam kehidupan manusia yang berlangsung seumur hidup. Adapun salah satu pendidikan yang berlangsung seumur hidup tersebut salah satunya bisa berupa pendidikan agama Islam.

Pendidikan agama Islam mempunyai pengertian yang sangat luas, sehingga para ahli agama mempunyai perbedaaan dalam memberikan definisi tentang pendidikan agama islam. Sedangkan pendidikan agama islam pada umumnya bersifat netral, artinya ilmu pengetahuan itu diajarkan sebagaimana adanya dan terserah kepada manusia yang hendak mengarahkan pengetahuan itu, yang mana pengajarannya mengarah pada pengetahuan, keterampilan, nilai dan sikap yang bersifat relatif sehingga arah dan tujuan dari pendidikan agama islam itu bisa terwujud.

Namun dalam hal ini pendidikan Islam yang dimaksudkan adalah bimbingan dan arahan terhadap anak didik agar nantinya setelah menyelesaikan pendidikannya dapat mendalami, menghayati, dan mempraktekkan serta menjadikan agama islam sebagai pandangan dan pegangan hidupnya demi kebahagiaan hidup di dunia dan di akhirat.

Adapun tujuan dari pendidikan agama Islam itu sendiri adalah membina insan paripurna yang takarrub pada Allah SWT Sehingga mendapat kebahagiaan di dunia dan akhirat. ${ }^{1}$ Dengan demikian, gagasan pendidikan agama islam seharusnya mampu merefleksikan manusia universal sebagai sumberdaya insaniah yang berkualitas dan yang banyak mengambil peran dalam kehidupan sehari-hari.

Salah satu lembaga pendidikan Islam adalah Taman Pendidikan Al-Qur'an (TPQ). Pendidikan agama di TPQ sangat sederhana dan tradisional yang mana sistem pengajaran agama islamnya menggunakan sistem bendungan, sorongan atau wetonan. Namun demikian, di TPQ terdapat nilai lebih karena lebih banyak mendapat pembelajaran dan bimbingan langsung dari kyai yang bersangkutan.

Demikian halnya di TPQ As-Sholihi Pajarakan-Probolinggo. Yang mana TPQ ini merupakan satu-satunya TPQ yang didirikan sejak jaman penjajahan belanda kurang lebih sekitar tahun 1940-an. Sejak pertama kali berdiri sampai sekarang TPQ ini masih berkualitas di mata masyarakat. Hal ini ditandai dengan banyaknya para santri yang menuntut ilmu serta dukungan yang diberikan masyarakat terhadap perkembangan pendidikan agama di TPQ tersebut.

Kelangsungan hidup suatu lembaga pendidikan keagamaan seperti TPQ sangat bergantung pada "daya tarik" tokoh sentral (kyai atau guru) yang memimpin, meneruskan dan mewarisinya. Jika pewaris menguasai sepenuhnya baik

${ }^{1}$ Djamaluddin \& A. Abdullah Aly, 1999, Kapita Selekta Pendidikan Islam, (Bandung: CV. Pustaka Setia), hal. 15. 
pengetahuan keagamaan, wibawa, keterampilan mengajar dan kekayaan lainnya yang diperlukan, maka umur lembaga akan bertambah lama. Sebaliknya lembaga akan menjadi mundur dan mungkin menghilang jika keturunan kyai yang mewarisinya tidak memenuhi persyaratan. Jadi seorang figur pemimpin sangat menentukan dan diperlukan terutama dalam pendidikan.

Sebab seorang pemimpin yang baik bukanlah komandan yang selalu mengatur, membentak dan selalu menyuruh pada bawahannya. Melainkan pemimpin yang baik kselalu bisa mempengaruhi orang lain dan bisa berkomunikasi melalui perasaaan serta mampu menanamkan nilai-nilai kepada anak buahnya, jadi kepemimpinan seorang pemimpin terutama dalam sebuah TPQ merupakan salah satu faktor penting dalam pencapaian tujuan yang ditentukan.

Adapun tujuan tersebut dipegang oleh orang yang mempunyai kemampuan, seperti halnya seorang kyai. Kyai di sini adalah orang yang memiliki ilmu pengetahuan dalam memegang tampuk kepemimpinan serta mempunyai sifat-sifat bawaan yang kharismatik. Dalam hal ini kepemimpinan seorang kyai menjadi sangat penting, sebab dia merupakan satu-satunya orang yang memiliki wewenang dalam mengembangkan TPQ itu sendiri.

TPQ adalah suatu lembaga pendidikan agama islam yang tumbuh serta diakui oleh masyarakat sekitarnya, yang mana santri-santrinya menerima pendidikan agama melalui sistem pengajaran yang sepenuhnya berada di bawah kedaulatan dan kepemimpinan seorang kyai dengan ciri khas yang bersifat kharismatik serta independen dalam segala hal. ${ }^{2}$

Sedangkan TPQ atau yang ada pada umumnya sering disebut sebagai cikalbakal pendidikan nasional dan diakui survive sejak jaman penjajahan, ternyata menyimpan beberapa pertanyaan, kenapa hal itu bisa terjadi?.

Berpangkal dari latar belakang di atas maka penulis tertarik untuk mengangkat judul tentang "Kepemimpinan Kyai Dalam Usaha Mengembangkan Pendidikan Islam Di TPQ As-Sholihi Pajarakan-Probolinggo”.

\section{B. Metode Penelitian}

\section{Pendekatan Penelitian}

Sesuai dengan sifat dan karakteristik dari penelitian kualitatif, maka studi ini menghasilkan data kualitatif yang merekonstruksikan ucapan dan tingkah laku orang atau subyek studi. Sebagaimana yang diucapkan oleh Bogdan dan Taylor mendefinisikan "metodologi kualitatif" sebagai prosedur penelitian yang menghasilkan data deskriptif berupa kata-kata tertulis atau lisan dari orang-orang dan prilaku yang diamati. Menurut mereka, pendekatan ini diarahkan pada latar dan individu secara holistik (utuh). Jadi, dalam hal ini

\footnotetext{
${ }^{2}$ Ibid, hal. 99.
} 
tidak boleh mengisolasikan individu atau organisasi ke dalam variabel atau hipotesis, tetapi perlu memandangnya sebagai bagian dari suatu keutuhan. ${ }^{3}$

Sesuai dengan permasalahan yang menjadi fokus masalah dalam penelitian ini, sebagaimana yang telah dijelaskan sebelumnya, maka penelitian ini menggunakan pendekatan kualitatif. Maksudnya ialah dalam penelitian kualitatif data yang dikumpulkan bukan merupakan angka-angka melainkan mungkin data tersebut berasal dari naskah wawacara, catatan lapangan, pengamatan dan pemanfaatan dokumen. ${ }^{4}$

Jika dikaitkan dengan penelitian di TPQ As-sholihi Pajarakan Probolinggo, maka data yang berasal dari lapangan hanya berupa naskah wawancara, catatan lapangan dan pengamatan langsung dari peneliti.

\section{Lokasi Penelitian}

Penelitian ini dilakukan di TPQ As-sholihi yang terletak di desa Pajarakan kecamatan Pajarakan kabupaten Probolinggo yakni di bawah asuhan Kyai Misbahul Arif. Peneliti memilih lokasi tersebut sebagai bahan penelitian karena ketertarikan peneliti pada tipe kepemimpinan yang digunakan oleh kyai Misbahul Arif terhadap pendidikan islam yang dikelolanya. Serta keadaan santri yang ada di TPQ tersebut rata-rata jumlahnya lebih banyak jika dibandingkan dengan TPQ lain yang berada di desa Pajarakan. Karena kebanyakan santri tersebut masih berusia dini, maka tidak heran jika karakteristik setiap individunya pun berbeda-beda. Dan hal ini menuntut para pemimpin khususnya pemimpin TPQ agar memiliki formulasi yang spesial dalam menanamkan pendidikan islam kepada para santrinya.

\section{Sumber Data}

Yang dimaksud dengan sumber data dalam penelitian, menurut Suharsimi Ari Kunto adalah subjek yang mana dapat diperoleh. ${ }^{5}$ Sumber data dalam penelitian ini berupa kata-kata dan tindakan melalui wawancara, fotofoto dengan beberapa responden/informan yang dianggap dapat memberikan informasi yang terkait dengan permasalahan yang diangkat peneliti. Sesuai dengan pendapat Lofland yang dikutip oleh Moleong, sumber data utama dalam penelitian kualitatif adalah kata-kata atau tindakan, selebihnya adalah data tambahan seperti dokumen dan lain-lain. ${ }^{6}$

\footnotetext{
${ }^{3}$ Lexy J. Moleong, 2006, Metodologi Penelitian Kualitatif edisi revisi, (Bandung: PT Remaja Rosdakarya), hal. 4.

${ }^{4}$ Ibid, hal. 5.

${ }^{5}$ Suharsimi Arikunto, 2006, Prosedur Penelitian Suatu Pendekatan Praktik, (Jakarta: PT Rineka Cipta), hal. 129.

${ }^{6}$ Lexy J. Moleong, Op.cit, hal. 157.
} 
Sumber data tersebut diperoleh dalam situasi yang wajar, maka data dalam penelitian ini dibedakan menjadi dua macam:

a. Data primer

Data primer adalah data yang dikumpulkan langsung oleh peneliti dari sumber pertamanya. Dalam penelitian ini, data primer yang diperoleh oleh peneliti adalah hasil wawancara peneliti dengan pemimpin TPQ As-sholihi Pajarakan.

b. Data sekunder

Data sekunder adalah data yang biasanya telah tersusun dalam bentuk dokumen-dokumen, misalnya data mengenai keadaan suatu daerah, dan sebagainya.

Data sekunder yang diperoleh oleh peneliti adalah data yang diperoleh langsung dari pihak-pihak yang berkaitan, di antaranya:

1) Wawancara dengan sebagian masyarakat dan sebagian alumni santri TPQ As-sholihi

2) Data santri TPQ As-sholihi dan berbagai literatur yang relevan dengan pembahasan

Selanjutnya penentuan sumber data atau informan dapat berkembang sesuai dengan kebutuhan dan kemantapan peneliti dalam pengumpulan data.

\section{Teknik Pengumpulan Data}

Menurut Lofland yang dikutip oleh moleong sumber data utama dalam penelitian kualitatif adalah kata-kata dan tindakan selebihnya adalah data tambahan seperti dokumen dan lain sebagainya. ${ }^{7}$ Sesuai dengan prosedur tersebut maka cara pengumpulan data dalam penelitian ini dilakukan dengan menggunakan tiga macam teknik pengumpulan data, yaitu:

a. Metode Observasi atau pengamatan

Metode observasi adalah pengamatan dan pencatatan dengan sistematik fenomena-fenomena yang diselidiki atau yang sedang diteliti. ${ }^{8}$ Metode ini digunakan oleh peneliti untuk memperoleh informasi yang mendalam terkait dengan tipe kepemimpinan dan usaha dalam mengembangkan pendidikan islam, antara lain: peneliti mengamati proses belajar mengajar, tehnik lain dan metode pengajaran, sarana dan prasarana serta interaksi yang timbul pada santri saat proses pembelajaran berlangsung di TPQ As-Sholihi Pajarakan-Probolinggo.

b. Metode wawancara atau Interview

\footnotetext{
${ }^{7}$ Ibid, hal. 157.

${ }^{8}$ Sutrisno Hadi, 2004, Metodologi Research jilid 2, (Yogyakarta: Andi Offset), hal. 151.
} 
Wawancara adalah percakapan dengan maksud tertentu. Percakapan itu dilakukan oleh dua pihak, yaitu pewawancara (interviewer) yang mengajukan pertanyaan dan yang diwawancarai yang memberikan jawaban atas pertanyaan itu. ${ }^{9}$ Dengan kata lain, wawancara dapat dipandang sebagai metode pengumpulan data dengan jalan tanya-jawab sepihak yang dikerjakan dengan sistematis dan berlandaskan kepada tujuan penelitian. ${ }^{10}$

Metode wawancara atau interview dipergunakan seseorang untuk tujuan suatu tugas tertentu, mencoba mendapat keterangan atau pendirian secara lisan dari seorang responden, yakni dengan bercakap-cakap dan berhadapan muka dengan orang itu.

Adapun metode wawancara secara mendalam ini akan dilakukan dengan pemimpin TPQ As-sholihi dan juga sebagian masyarakat dan alumni dari TPQ As-sholihi itu sendiri. Metode wawancara ini dilakukan untuk memperoleh data tentang sejarah singkat berdiri dan berkembangnya TPQ As-Sholihi, pengertian kepemimpinan menurut kyai yang bersangkutan dan usaha yang dilakukan dalam upaya untuk mengembangkan pendidikan islam, serta target yang telah dan belum dicapai begitu juga dengan faktor pendukung dan penghambat dalam usaha pengembangan pendidikan islam di TPQ AS-Sholihi tersebut.

c. Metode Dokumentasi

Tidak kalah penting dari metode-metode lain, adalah metode dokumentasi. Dokumentasi adalah asal kata dari dokumen yang artinya barang-barang tertulis. Sedangkan dalam istilah lain dokumentasi yaitu mencari data mengenai hal-hal atau variable yang berupa catatan transkip, buku, surat kabar, majalah, prasasti, notulen rapat, dan sebagainya. ${ }^{11}$ Dibandingkan dengan metode lain, maka metode ini paling mudah, dalam artian apabila ada kekeliruan sumber datanya masih tetap dan belum berubah. Dengan metode ini yang diamati bukan benda hidup melainkan benda mati. Jadi dalam penelitian ini peneliti menggunakan metode dokumentasi hanya ingin mengambil atau memperoleh data santri yang ada di TPQ As-sholihi.

Ketiga metode pengumpulan data di atas digunakan secara simultan, dalam arti digunakan untuk saling melengkapi antara data yang satu dengan data yang lain.

\section{Analisis Data}

\footnotetext{
${ }^{9}$ Lexy J. Moleong, Op.cit, hal. 186.

${ }^{10}$ Sutrisno Hadi, Op.cit, hal. 218.

${ }^{11}$ Suharsimi Arikunto, Op.cit, hal. 231.
} 
Istilah analisis data diadopsi dari kata analysis, yang dalam konteks riset kegiatan analisis merupakan proses kerja dari rentetan tahapan pekerjaan sebelum riset di dokumentasikan melalui tahapan penulisan laporan. ${ }^{12}$

Pada analisis data kualitatif, kata-kata disusun dari hasil wawancara atau pengamatan terhadap data yang dibutuhkan untuk mendeskripsikan dan dirangkum. Analisis data adalah kelajutan dari pengolahan data. ${ }^{13}$ Data yang telah diperoleh dengan cara observasi atau pengamatan, wawancara semi terstruktur dan dokumentasi tersebut diproses melalui perekaman/pencatatan dan pengetikan akan tetapi analisis kualitatif tetap menggunakan kata-kata yang biasanya di dalam teks yang diperluas. Adapun analisis data dalam penelitian ini menggunakan tiga alur, yang mana ketiga alur tersebut adalah:

a. Reduksi

Reduksi data diartikan sebagai proses pemilihan, pemusatan, perhatian dan penyederhanaan, pengabstrakan dan transformasi data yang muncul dari catatan-catatan lapangan.

Terkait dengan penelitian di TPQ As-sholihi Pajarakan, peneliti akan menyederhanakan dan mentransformasikan data yang telah diperoleh (melalui pengamatan, wawancarawawancara semi tersruktur dengan pemimpin TPQ dan dokumenter) dengan cara menyeleksi, meringkas, atau uraian singkat dan menggolongkannya dalam suatu pola yang lebih luas sampai akhirnya kesimpulan akhir dan diverifikasi.

b. Penyajian data

Bagian kedua dari analisi data adalah penyajian data. yang dimaksud penyajian data adalah sekumpulan informasi yang tersusun yang memberi kemungkinan adanya penarikan kesimpulan dan pengambilan tindakan.

Pada bagian kedua ini, setelah mereduksi data peneliti sudah dapat mengumpulkan informasi yang dapat memberikan peluang untuk mengambil kesimpulan. Sehingga data dapat tersaji dengan baik tanpa adanya data yang sudah tidak dibutuhkan.

c. Penarikan kesimpulan

Penarikan kesimpulan hanyalah sebagian dari suatu kegiatan dari konfigurasi yang utuh. Verifikasi dapat dilakukan untuk mencari pembenaran dan persetujuan, sehingga validitas dapat tercapai.

Setelah data terkumpul dilakukan pemilihan secara selektif disesuaikan dengan permasalahan yang diangkat dalam penelitian selain itu, dilakukan pengolahan dengan proses editing, yaitu dengan meneliti kembali

${ }^{12}$ Husein Umar, 2004, Metode Riset Ilmu Administrasi, (Jakarta: PT Gramedia Pustaka Utama), hal. 112.

${ }^{13}$ Nana Sudjana, 2005, Tuntunan Penyusunan Karya Ilmiah, (Bandung: Sinar Baru Algesindo), hal. 78. 
data-data yang didapat, apakah data tersebut sudah cukup baik dan dapat segera dipersiapkan untuk proses berikutnya. Secara sistematis dan konsisten bahwa data yang diperoleh dituangkan dalam suatu rancangan konsep yang kemudian dijadikan dasar utama dalam analisis.

Analisis data menurut Bogdan dan Biklen dalam Moleong, ialah upaya yang dilakukan dengan jalan bekerja dengan data, mengorganisasikan data, memilah-milahnya menjadi satuan yang dapat dikelola, mensintesiskannya, mencari dan menemukan pola, menemukan apa yang penting dan apa yang dipelajari, dan memutuskan apa yang dapat diceritakan kepada orang lain. ${ }^{14}$

Dalam penelitian ini yang digunakan dalam menganalisa data yang sudah diperolaeh adalah dengan cara deskriptif (non statistik), yaitu penelitian yang dilakukan dengan menggambarkan data yang diperoleh dengan kata-kata atau kalimat yang dipisahkan untuk kategori untuk memperoleh kesimpulan, yang bermaksud mengetahui keadaan sesuatu mengenai apa dan bagaimana, berapa banyak, sejauh mana dan sebagainya.

\section{Keabsahan Data}

Keabsahan data merupakan konsep penting yang diperbaharui dari konsep kesahihan (validitas) dan keandalan (eliabilitas), menurut versi "positivisme" dan disesuaikan dengan tuntunan pengetahuan paradigmanya sendiri.

Pemeriksaan keabsahan data didasarkan atas sejumlah kriteria tertentu. Ada empat kriteria yang digunakan, yaitu: derajat kepercayaan (kredibilitas), keteralihan, kebergantungan, dan kepastian. ${ }^{15}$ Masing-masing kriteria tersebut menggunakan teknik pemeriksaan sendiri-sendiri. Kriteria derajat kepercayaan pemeriksaan datanya dilakukan dengan:

a. Teknik perpanjangan keikutsertaan, ialah untuk memungkinkan peneliti terbuka terhadap pengaruh ganda, yaitu: faktor-faktor kontekstual dan pengaruh bersama pada peneliti dan subyek yang akhirnya mempengaruhi fenomena yang diteliti;

b. Ketekunan pengamatan, bermaksud menemukan ciri-ciri dan unsur-unsur dalam situasi yang sangat relevan dengan persoalan dan isu yang kadang dicari dan kemudian memusatkan diri pada hal-hal tersebut secara rinci;

c. Triangulasi, adalah teknik pemeriksaan keabsahan data yang memanfaatkan sesuatu yang lain diluar data itu untuk keperluan pengecekan atau sebagai perbandingan terhadap data tersebut. Teknik

\footnotetext{
${ }^{14}$ Lexy J. Moleong, Op.cit, hal. 248.

15 Ibid, hal. 324.
} 
triangulasi yang paling banyak digunakan ialah pemeriksaan melalui sumber lainnya;

d. Pengecekan atau diskusi sejawat, dilakukan dengan cara merespon hasil sementara atau hasil akhir yang diperoleh dalam bentuk diskusi analitik dengan rekan-rekan sejawat;

e. Kecukupan referensial, alat untuk menampung dan menyesuaikan dengan kritik tertulis untuk keperluan evaluasi. Film atau video, hand phone misalnya dapat digunakan sebagai alat perekam yang pada saat senggang dapat digunakan untuk membandingkan hasil yang diperoleh dengan kritik yang terkumpul;

f.Kajian kasus negative, dilakukan dengan jalan mengumpulkan contoh dan kasus-kasus yang tidak sesuai dengan pola dan kecenderungan informasi yang telah dikumpulkan sebagai bahan pembanding;

g. Pengecekan anggota dicek dengan anggota yang terlibat meliputi data, kategori analisis, penafsiran dan kesimpulan. Yaitu salah satunya seperti akhtisar wawancara dapat diperlihatkan untuk dipelajari oleh satu atau beberapa anggota yang terlibat, dan mereka diminta pendapatnya.

h. Auditing, adalah konsep bisnis khususnya dibidang fiskal yang dimanfaatkan untuk memeriksa kebergantungan dan kepastian data yang ada. $^{16}$

Demikian halnya dengan penelitian ini, secara tidak langsung peneliti telah menggunakan teknik pemeriksaan keabsahan data dengan menggunakan kriteria kebergantungan dan kepastian pemeriksaan yakni dengan teknik auditing untuk membuktikan kepastian data. Yaitu dengan kehadiran peneliti sebagai instrumen, mencari tema atau penjelasan pembanding atau penyaing, membandingkan data hasil pengamatan dengan data hasil wawancara, mengadakan wawancara dengan beberapa orang yang berbeda, menyediakan data deskriptif secukupnya, diskusi dengan temanteman sejawat.

\section{Hasil dan Pembahasan}

Setelah peneliti mengumpulkan data dari hasil penelitian yang diperoleh dari wawancara, observasi, dan data dokumentasi maka selanjutnya peneliti akan melakukan analisa data untuk menjelaskan lebih lanjut dari hasil penelitian.

Sesuai dengan tehnik analisa data yang dipilih oleh peneliti yaitu peneliti menggunakan analisis kualitatif deskriptif (pemaparan) yaitu dengan menganalisa data yang telah peneliti kumpulkan dari hasil wawancara, observasi, dan dokumentasi selama peneliti mengadakan penelitian dengan lembaga terkait. Adapun data yang diperoleh dan dipaparkan oleh peneliti akan di analisa oleh

\footnotetext{
${ }^{16}$ Ibid, hal. 327-338.
} 
peneliti sesuai dengan hasil penelitian yakni sebagai berikut:

1. Tipe kepemimpinan kyai di TPQ As-sholihi Pajarakan Probolinggo

a. Tipe kepemimpinan kharismatik

Kepemimpinan kharismatik jika dikaitkan dengan tipe TPQ adalah kepemimpinan yang bersandar pada kepercayaan santri atau masyarakat umum sebagai jam'ah, bahwa kyai merupakan pemimpin TPQ yang mempunyai kekuasaan dari Allah SWT.

Dari uraian tersebut dapat dipastikan bahwa tipe kepemimpinan kharismatik sangat dibutuhkan dalam mengelola TPQ. Demikian juga di TPQ As-sholihi, jika diamati kepemimpinan kharismatik juga digunakan dalam tipe kepemimpinannya, yakni dengan adanya sumber-sumber kewibawaan pemimpin TPQ dibawah ini:

1) Memiliki kekuatan energi yang luar biasa, misalnya program-program yang berlangsung di TPQ tersebut masih mendapat perhatian langsung yang sebagai mana mestinya. Seperti pada program pembelajaran tartil Qur'an, khatmil Qur'an, dan penbelajaran kitab. Yang mana sistem pengajaran program ini masih ditangani langsung oleh kyai atau pemimpin TPQ.

2) Memiliki daya tarik dan pembawaan yang luar biasa untuk mempengaruhi orang lain. Adapun daya tarik yang ada meliputi: kulaitas pribadi (seperti: penguasaan hukum islam, Al-Quran, dan kitab-kitab tertentu), sedangkan pembawaan memiliki sikap percaya diri dan pendirian yang kuat.

b. Tipe kepemimpinan otoriter

Kepemimpinan otoriter merupakan salah satu dari tipe kepemimpinan yang digunakan di TPQ As-sholihi Pajarakan disamping tipe kepemimpinan kharismatik. Hal tersebut sangat tampak terutama jika dikaitkan dengan proses pemberian hukuman/punishment kepada santri yang sifatnya tidak mau diperingatkan. Adapun prosedur yang digunakan dalam pemberian hukuman/punishment dalam kepemimpinan otoriter di TPQ As-sholihi adalah:

1) Konsultasi dan pengambilan keputusan bersama; biasanya dilakukan antara pemimpin TPQ, masyarakat dan wali santri dalam sebuah forum kemudian mereka duduk bersama untuk menyepakati sebuah kebijakan.

2) Pemberian hukuman dilakukan dengan cara mendidik santri agar dia mengerti dan faham akan pentingnya pendidikan, misalnya dengan menyuruh dia menghafalkan ayat-ayat Al-Qur'an atau menulis ayat tersebut dalam lembaran kertas.

c. Tipe kepemimpinan Demokratis 
Pemimpin demokratis menciptakan suasana yang demokratis. Dengan gaya ini pemimpin berusaha membawa mereka yang dipimpin menuju ketujuan dan cita-cita dengan memperlakukan mereka sebagai sejawat yang sejajar. Dalam tipe kepemimpinan ini batas antara pemimpin dan bawahan menjadi kabur, orang diberi tempat yang sederajat.

Dengan memperhatikan seluruh kaidah yang ada dalam tipe kepemimpinan demokrasi, maka kepemimpinan demokrasi akan sangat tepat untuk diterapkan dalam sebuah TPQ. Jika dikaitkan dengan tipe kepemimpinan yang ada di TPQ As-sholihi maka tipe kepemimpinan demokratislah yang sangat mendominasi diantara tipe-tipe kepemimpinan yang lain, dengan kriteria sebagai berikut:

1) Selalu mempertimbangkan kapasitas dan kemampuna masing-masing manusia sebagai individu, sebagai implementasi dari pandangan bertitik tolak bahwa manusia adalah makhluk yang termulia didunia.

2) Senang menerima saran, pendapat dan kritik dari bawahan, terlebih ketika musyawarah berlangsung.

3) Mengutamakan kerjasama dalam usaha mencapai tujuan, misalnya: dalam berbagai kegiatan yang ada.

2. Usaha kyai dalam mengembangkan pendidikan islam di TPQ As-sholihi Pajarakan

a. Peningkatan kompetensi santri

Dari data lapangan yang ada dapat disimpulkan bahwa pembelajaran tartil Qur'an, khatmil qur'an dan pembelajaran kitab merupakan salah satu usaha kyai dalam mengembangkan pendidikan islam, yang sesuai dengan program kegiatan TPQ untuk mencapai visi dan misi yang telah ditentukan sebelumnya.

Adapun program peningkatan kompetensi santri seperti pembelajaran tartil Qur'an, ini dilaksanakan setiap hari yakni setelah sholat magrib dan sholat subuh. Dan kegiatan khatmil quran dilaksanakan satu kali dalam sebulan yang mana program ini diikuti oleh semua santri dan masyarakat yang tinggal disekitar TPQ. Sedangkan pembelajaran kitab dilaksanakan setiap hari setelah sholat asyar dan program ini hanya diikuti oleh semua santri TPQ As-sholihi.

b. Peningkatan kualitas dan kuantitas ibadah

Data-data lapangan yang ada dapat menyimpulkan bahwa kultum tentang sholat, dzikir dan puasa serta pentradisian sholat-sholat sunnah merupakan salah satu usaha kyai dalam mengembangkan pendidikan islam, dan kegiatan tersebut merupakan kegiatan yang 
ditetapkan di TPQ untuk mewujudkan visi dan misi TPQ dalam mengantarkan santri memiliki kekokohan aqidah dan kedalaman spiritual.

Adapun kegiatan ini berhubungan dengan I'tiqat batin, mengajarkan keEsa-an Allah SWT. Esa sebagai Tuhan yang mencipta, mengatur dan meniadakan alam ini. Selain itu kegiatan ini juga berhubungan dengan amal lahir dalam rangka mentaati semua peraturan dan hukum Tuhan, guna mengatur hubungan antara manusia dengan Tuhan dan mengatur pergaulan hidup dan kehidupan manusia serta sifat yang tertanam dalam jiwa, dari padanya timbul perbuatan yang mudah tanpa memerlukan pertimbangan pemikiran.

Berdasarkan pada teori dan hasil penelitian diatas maka fungsifungsi kepemimpinan yang telah dilakukan untuk merealisasikan kegiatan tersebut adalah fungsi konsultatif dengan adanya komunikasi dua (2) arah antara pemimpin TPQ/kyai dengan masyarakat. Fungsi delegasi dengan adanya pemberian kewenangan kepada masyarakat untuk memberikan usulan-usulan yang positif. Dan fungsi keteladanan pada saat program penigkatan kualitas dan kuantitas ibadah dilakukan.

\section{Kesimpulan}

Berdasarkan hasil penelitian lapangan dan analisis data dari data observasi, data wawancara dan data dokumentasi maka peneliti dapat menyimpulkan beberapa hal sebagai berikut:

1. Umum

Pelaksanaan Kepemimpinan Kyai dalam Usaha Mengembangkan Pendidikan Islam di TPQ As-sholihi Pajarakan-Probolinggo cukup baik, dibuktikan dengan cukup berperannya Kyai dalam Mengembangkan Pendidikan Islam di TPQ As-sholihi.

2. Hipotesa Kerja Minor

a. Tipe kepemimpinan kyai di TPQ As-Sholihi Pajarakan, meliputi: kepemimpinan otoriter (authoritative leadership), kepemimpinan karismatik (spiritual leadership), dan kepemimpinan demokrasi (democrative leadership), yang mana ketiga tipe ini digunakan oleh kyai Misbahul Arif khususnya dalam memimpin TPQ As-Sholihi Pajarakan. Ketiga tipe kepemimpinan ini diterapkan pada program pengembangan sumber daya manusia/SDM (segi penerimaan santri baru), program peningkatan keterampilan, peningkatan kompetensi santri, dan peningkatan kualitas dan kuantitas ibadah, yakni dengan indikator keberhasilan; adanya penanggung jawab pemimpin TPQ pada masingmasing program dan kerja sama dengan masyarakat atau wali santri 
dalam program tersebut sehingga ada keputusan bersama yang baik demi terealisasinya program TPQ tersebut.

b. Usaha kyai dalam mengembangkan pendidikan islam di TPQ As-Sholihi Pajarakan adalah:

1) Peningkatan kompetensi santri

Program kegiatan tersebut secara langsung di bawahi oleh pemimpin atau pengasuh TPQ, sebagai penanggung jawab yang merupakan penerjemah dari visi dan misi TPQ, yakni mengantarkan santri memiliki kemantapan akidah dan kedalaman spiritual, dengan cara pembelajaran tartil Qur'an, khotmil Qur'an, dan pembelajaran kitab.

2) Peningkatan kualitas dan kuantitas ibadah

Secara operasional, kegiatan-kegiatan tersebut di atas berada dalam tanggung jawab pemimpin atau pengasuh TPQ dan merupakan kegiatan yang ditetapkan di TPQ untuk mewujudkan visi dan misi TPQ As-sholihi dalam mengantarkan santrinya memiliki kekokohan akidah dan kedalaman spiritual. Adapun program tersebut dilaksanakan dalam bentuk kultum tentang sholat, dzikir, dan puasa serta pentradisian sholat-sholat sunnah. 


\section{Daftar Pustaka}

Abu Ahmadi \& Nur Uhbiyati. 2001. Ilmu Pendidikan. Jakarta: PT. Rineka Cipta.

Al-Qur'an \& Terjemah. 2002. Surabaya: Al-hidayah.

Al-Syaibany, Omar Al-Toumy M. 1979. Falsafah Pendidikan Islam. Jakarta: Bulan Bintang.

Anwar, Desi. 2003. Kamus Lengkap Bahasa Indonesia Terbaru. Surabaya: Amelia.

Arifin, Imron. 1993. Kepemimpinan Kyai Kasus Pondok Pesantren Tebu Ireng. Malang: Kalimasahada Press.

Arifin M. 1989. Ilmu Pendidikan Islam. Jakarta: Bumi Aksara.

Arifin, Muzayyin. 2007. Kapita Selekta Pendidikan Islam. Jakarta: PT. Bumi Aksara.

Arikunto, Suharsimi. 2006. Prosedur Penelitian Suatu Pendekatan Praktik. Jakarta: PT. Rineka Cipta.

Basri, Hasan. 1994. KHR. As'ad Syamsul Arifin Riwayat Hidup dan Perjuangannya. Surabaya: CV. Sahabat Ilmu.

Dahlan, Al-bahri. 1994. Kamus IlmiahPopuler. Yogyakarta: Arloka.

Daradjat, Zakiah. 1992. Ilmu Pendidikan Islam. Jakarta: Bumi Aksara.

Djamaluddin \& Ali, Abdullah. 1999. KapitaSelekta Pendidikan Islam. Bandung: CV. Pustaka Setia.

Depag RI. 2000. Studi tentang Wajib Belajar Pendidikan Dasar. Jakarta.

Fathurrozi. 2008. Taman Pendidikan Al-Qur'an suatu Pendekatan Praktek Pembelajaran Al-Qur'an. Yogyakarta: Pustaka Belajar.

Hadi, Sutrisno. 2004. Metodologi Reseach Jilid 2. Yogyakarta: Andi Offset.

Hafidz Iqbal Wira Damiri. 2008. Strategi Kepemimpinan Kepala Madrasah dalam Meningkatkan Profesionalisme Guru. Probolinggo: Institut Keislamam Hasyim Asy'ari.

Hamalik, Oemar. 2008. Proses Belajar Mengajar. Jakarta: PT. Bumi Aksara. 
Hamdani Ihsan \& Fuad Ihsan. 2001. Filsafat Pendidikan Islam. Bandung: Pustaka Setia.

Hartono A. Jais \& Akaha, A. Zulfidar. 2005. Bila Kyai Dipertuhankan Membedah Sikap Beragama NU. Jakarta: Pusaka Al-Kautsar.

Hasbullah. 2005. Dasar-dasar Ilmu Pendidikan Edisi Revisi. Jakarta: PT. Raja Grafindo Persada.

Hery Nur Aly \& Munzir S. 2008. Watak Pendidikan Islam. Jakarta: Friska Agung Insani.

Langgulung, Hasan. 2003. Asas-asas Pendidikan Islam. Jakarta: PT. Pustaka Alhusna Baru.

Marimba, Ahmad D. 1962. Pengantar Filsafat Pendidikan Islam. Bandung: PT. Alma'arif.

Moleong, J. Lexy. 2006. Metodologi Pendidikan Kualitatif Edisi Revisi. Bandung: PT. Remaja Rosdakarya.

Sudjana, Nana. 2005. Tuntunan Penyusunan Karya Ilmiah. Bandung: Sinar Baru Algesindo.

Suthon \& Khusnuridlo, Moh. 2006. Manajemen Pondok Pesantren Dalam Perspektif Global. Yogyakarta: Laksbang PRESSindo.

Tohirin. 2006. Psikologi Pembelajaran agama Islam. Jakarta: PT. Raja Grafindo Persada.

Trisno Yuwono \& Abdullah, Pius. 1994. Kamus Lengkap Bahasa Indonesia Praktis. Surabaya: Arloka.

Umar, Husain. 2004. Metode Riset Ilmu Administrasi. Jakarta: PT. Gramedia Pustaka Utama. 